\title{
The Relationship between Innovation and Firm Performance: A Literature Review
}

\author{
Shouyu Chen \\ Zhejiang Yuexiu University of Foreign Languages, Shaoxing, P.R.China \\ chenshyu@zju.edu.cn
}

Keywords: Innovation; Firm performance; Moderating effect; Mediating effect

\begin{abstract}
Innovation has been generally regarded as a key factor affecting firm performance. Many companies try their best to achieve higher profits through innovation in different ways. However, the literature shows that the impact of innovation on firm performance is different among many innovative firms. This article will review the related literature from three aspects: the direct impact of innovation on enterprise performance, the moderating effect of innovation on firm performance, the mediating effects between innovation and firm performance.
\end{abstract}

\section{Introduction}

Since Schumpeter put forward the important role of innovation in economic development in 1934, innovation has been widely regarded as the key factor affecting enterprise performance. In fact, many companies seek ways to achieve greater profits through innovations of different types or ways. However, the existing literature shows that the impact of innovation on firm performance is not consistent in many innovative firms. Innovation as a single variable, it is difficult to establish a simple relationship with enterprise performance. Therefore, many studies, especially in the field of enterprise strategy, have analyzed the relationship between innovation and firm performance. The paper will review the related literature from three aspects: the direct impact of innovation on enterprise performance, the moderating effect of innovation on firm performance, the mediating effects between innovation and firm performance.

\section{The Direct Impact of Innovation on Enterprise Performance}

Many studies have confirmed innovation has a positive impact on enterprise performance. Roberts found that in the long run, innovation activities had a positive impact on the ROI of firms after studying the American pharmaceutical industry [1], Cho and Pucik based on the empirical study of Fortune 1000 companies, concluded that the innovation of enterprises was positively related to the growth and profitability of enterprises [2]. Hua investigated the relationship between the ratio of new products and performance, found in the personal computer industry, there was a positive correlation between the two, and put forward if the enterprise sustainable develop a series of a new product, they can get high profit [3]. In addition to the manufacturing sector, Salavou and Prajogo, respectively, studied Greek and Australian service industries and found that product innovation was an important determinant of growth and profitability in service business [4][5]. Other relevant studies have confirmed that the more innovative firms are, the more likely they are to achieve higher corporate performance [6].

However, successfully developed and introduced innovation to get the benefits of innovation needs specific organizational resources and capabilities. Because innovation also show a multi-faceted, the performance of innovation in different enterprise may not be the same in the different environment. For example, innovation may also be resisted, including corporate internal boycotts and market boycotts, so that the impact of innovation on firm performance is likely to have no effect. Once an enterprise adopts an innovation, it may force employees, suppliers, and customers to use it, and these people may not realize the importance of this innovation to them. Ram and Jung found that some members of the organization may also resist innovation if they are forced to adopt an innovation [7]. The sales staff may also worry about engaged in the sales of new 
products reducing their performance, and then produce to resist on the new product [8], resulting in product innovation is not easy to be accepted by the market. At the same time, innovation usually consumes a large amount of resources. Therefore, innovation related activities may not directly improve firm performance.

\section{The Moderating Effect of Innovation on Firm Performance}

Environmental uncertainty and dynamic change lead to enterprise's innovative activities, while innovation contributes to the improvement of enterprise performance. However, some studies have shown that the relationship between innovation and corporate performance is not so direct, which is influenced by the impact of competition environment. Huang and Rice point out that the relationship between innovation input and firm performance is not deterministic, and it is affected by internal capital stock, external market and environmental factors [9].

In a stable environment, producers, customers and suppliers do not easily want to change. Therefore, the innovative behavior of an enterprise may have a negative impact on its performance. Innovation is unlikely to be useful if the market is unwilling to change the existing state. Customers who want to stay current and existing standards or norms push innovative firms into adverse competitive positions [10]. The rigidity of the structure and the inertia of the organization may also stifle innovation activities, and thereby affect the whole industry. In a stable competitive environment, the leaders of the industry rarely innovate first to destroy the existing environment, but to cultivate the market and pave the way for new products to be introduced gradually.

In a dynamic environment, innovation plays a positive role in enterprise performance. In a dynamic industry, change is the normal. Enterprises must innovate to keep pace with change. In such an environment, non-innovators may be eliminated, while innovators can retain a favorable competitive position. In the uncertain environment, innovative enterprises always beat the non-innovation enterprises in the dynamic environment [11]. The dynamic environment allows new entrants to be more innovative and entrepreneurial, thus gaining growth and profits [12].

After the case study of the furniture manufacturing enterprises in Italy, Spain and Finland, Otero-Neira et al. found that the impact of innovation on business performance influenced by the industry environment [13]. In Spain, the channel competition affects enterprise innovation profit; in Finland, a small domestic market limited profits of innovation; while in Italy, because the company's products are mainly sold in the international market, the enterprise performance is affected by the international market significantly, and the international market become the key to the success of the furniture industry in the future.

\section{The Mediating Effects between Innovation and Firm Performance}

Using a sample of 449 Australian manufacturing companies from the Business Longitudinal Survey from the Australian Bureau of Statistics, Liao and Rice developed a mediated model by which they examined the impact of innovation on firm performance mediated through a firm's market engagement and transformation strategies [14]. This paper found that organisational performance was driven by innovation mediated by the transformation outcomes, and innovation related activities can drive a firm's competitive advantage only when they occur concomitantly with actual changes in the market position and offerings of firms. Three types of transformation outcomes, principally derived from Schumpeterian models, have been employed by this paper, namely changes in the range of products/services, distribution of products/services and market targets.

By integrating innovation performance analysis method, Günday et al. constructed the model that four different types of innovation (products, process, marketing and organization), through the intermediary role of the enterprise innovativeness, impacted on the performance of market, production and financial [15]. Through the empirical study of 184 manufacturing enterprises in Turkey, they tested the relationship between innovation and enterprise performance. The research results showed that innovativeness played a mediating role in the impact of various innovations on firm performance. 
Neely et al. provided a reference model to research the relationship between business performance, innovation and the internal and external factors which can facilitate innovation within a company. In the framework (Fig. 1) they have included an intermediate block of variables, called "outcomes of innovation", which refers to the efficacy of innovation in getting, for example, lower costs and/or better service. In other words, the outcomes of innovation are the results of the exploitation of the different kind of innovation [16].

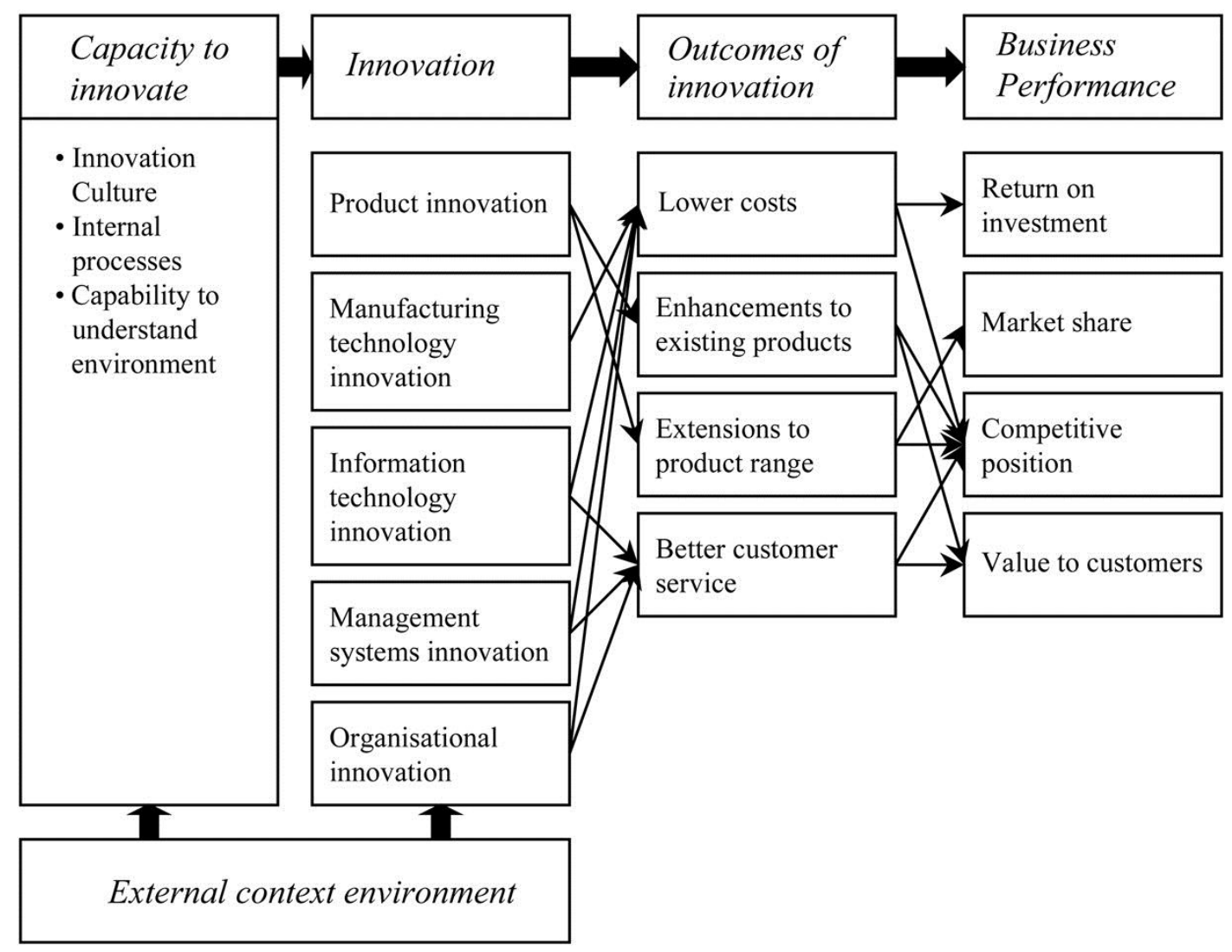

Figure 1. Links between types of innovation and outcomes of innovation

Finally, Zott pointed out that the firm's market position plays a mediating effect between innovation and firm performance [17].

\section{Conclusion}

Based on the above analysis, there are three different views on the impact of innovation on enterprise performance (Table 1). The first point of view is that innovation can directly affect the performance of enterprises, showing positive, no effect, or negative effect. The second point of view is that some moderating variables affect the relationship between innovation and business performance, and the main moderating variable is the industrial environment or market environment. The third view is that the mediating effect between innovation and enterprise performance, the main mediating variables include the change of industry, innovation output, IT investment, product matching and process matching, innovation, market position etc. The summary of these researches can provide the direction for further research, on the other hand can also help us recognize the mechanism between innovation and enterprise performance, which can improve the performance of innovation. 
Table 1 Research on the relationship between innovation and enterprise performance

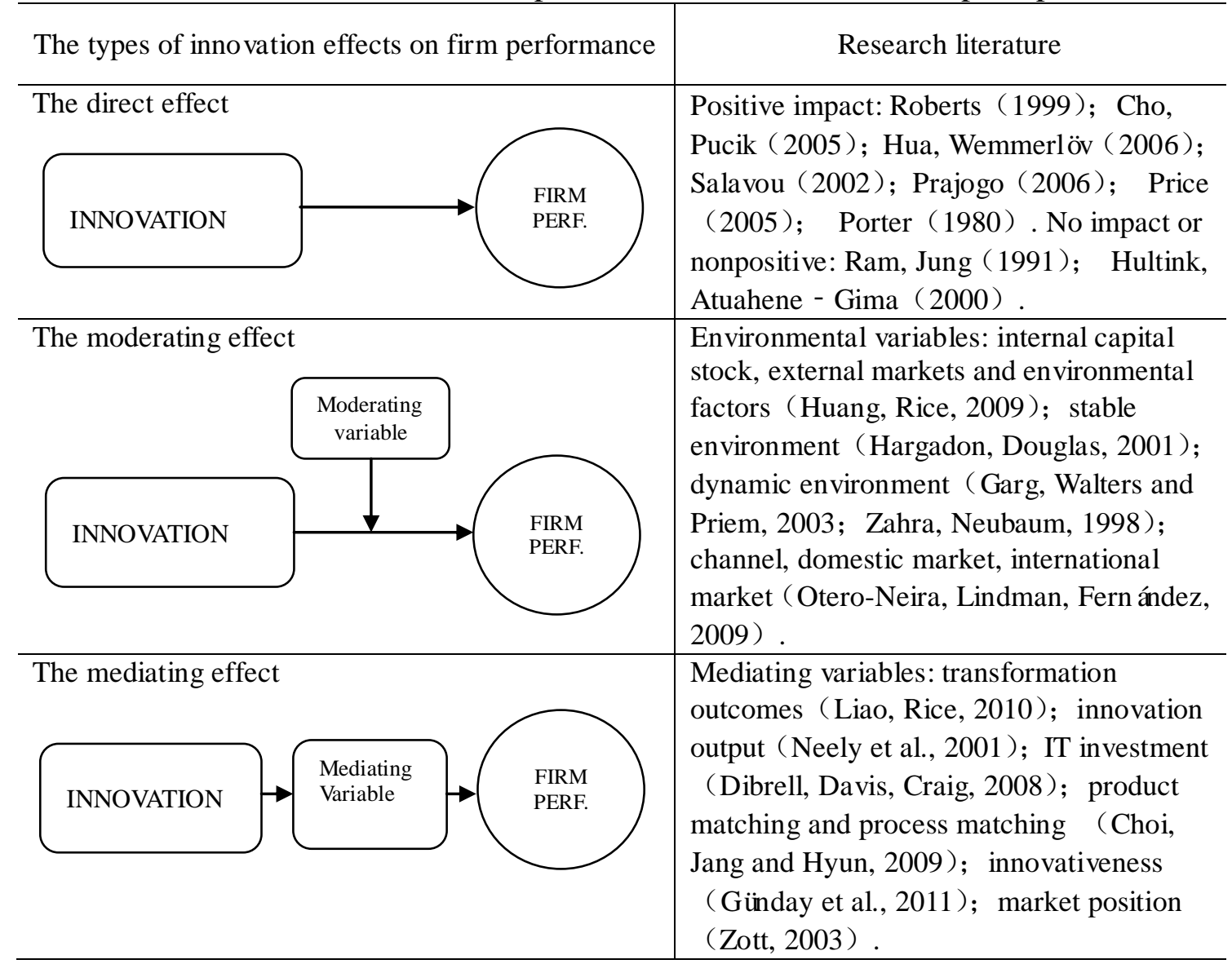

\section{References}

[1] Roberts, P. W. Product innovation, product-market competition and persistent profitability in the US pharmaceutical industry. Strategic Management Journal, 1999, 20(7): 655-670.

[2] Cho, H. J., Pucik, V. Relationship between innovativeness, quality, growth, profitability, and market value. Strategic Management Journal, 2005, 26(6): 555-575.

[3] Hua, S. Y., Wemmerlöv, U. Product change intensity, product advantage, and market performance: an empirical investigation of the PC industry. Journal of Product Innovation Management, 2006, 23(4): 316-329.

[4] Salavou, H. Profitability in market-oriented SMEs: does product innovation matter? European Journal of Innovation Management, 2002, 5(3): 164-171.

[5] Prajogo, D. I. The relationship between innovation and business performance - a comparative study between manufacturing and service firms. Knowledge and Process Management, 2006, 13(3): 218-225.

[6] Price, R. M. Technology and strategic advantage. Operations Management: A Strategic Approach, 2005, 164-178.

[7] Ram, S., Jung, H. S. "Forced" adoption of innovations in organizations: Consequences and implications. Journal of Product Innovation Management, 1991, 8(2), 117-126.

[8] Hultink, E. J., Atuahene-Gima, K. The effect of sales force adoption on new product selling performance. Journal of Product Innovation Management, 2000, 17(6), 435-450.

[9] Huang, F., Rice, J. The role of absorptive capacity in facilitating Open innovation outcomes: A study of Australian SMEs in the manufacturing sector. International Journal of Innovation Management, 2009, 13(02), 201-220.

[10] Hargadon, A. B., Douglas, Y. When innovations meet institutions: Edison and the design of the electric light. Administrative Science Quarterly, 2001, 46(3), 476-501. 
[11] Garg, V. K., Walters, B. A., Priem, R. L. Chief executive scanning emphases, environmental dynamism, and manufacturing firm performance. Strategic Management Journal, 2003, 24(8), 725-744.

[12]Zahra, S. A., Neubaum, D. O. Environmental adversity and the entrepreneurial activities of new ventures. Journal of Developmental Entrepreneurship, 1998, 3(2), 123-140.

[13] Otero-Neira, C., Lindman, M. T., Fernández, M. J. Innovation and performance in SME furniture industries: An international comparative case study. Marketing Intelligence \& Planning, 2009, 27(2), 216-232.

[14]Liao, T. S., Rice, J. Innovation investments, market engagement and financial performance: A study among Australian manufacturing SMEs. Research Policy, 2010, 39(1), 117-125.

[15] Gunday G, Ulusoy G, Kilic K, et al. Effects of innovation types on firm performance. International Journal of Production Economics, 2011, 133(2): 662-676.

[16] Neely, A., Filippini, R., Forza, C., Vinelli, A., Hii, J. A framework for analysing business performance, firm innovation and related contextual factors: Perceptions of managers and policy makers in two European regions. Integrated Manufacturing Systems, 2001, 12(2), 114-124.

[17] Zott, C. Dynamic capabilities and the emergence of intraindustry differential firm performance: Insights from a simulation study. Strategic Management Journal, 2003, 24(2), 97-125. 